\title{
Digital branding Kantor Arsip Universitas Padjadjaran dalam upaya penguatan reputasi
}

\author{
Wawat Setiawati ${ }^{1}$, Wina Erwina ${ }^{2}$, Susie Perbawasari ${ }^{3}$ \\ Universitas Padjadjaran, Bandung, Indonesia
}

\begin{abstract}
ABSTRAK
Kantor Arsip Universitas Padjadjaran sebagai lembaga kearsipan perguruan tinggi, dibentuk untuk menyelamatkan arsip penting yang berkaitan dengan bukti status intelektualitas serta mengembangkan potensi yang melahirkan inovasi dan karya-karya intelektual lainnya. Arsip yang tercipta di Universitas Padjadjaran, merupakan aset publik yang menjadi bukti akuntabilitas kinerja dan bahan pertanggungjawaban atas capaian Tri Dharma Perguruan Tinggi. Di era digital saat ini, Kantor Arsip Universitas Padjadjaran dihadapkan pada situasi yang sangat terbuka, dimana akses informasi terkait arsip statis harus mudah di akses oleh masyarakat dengan cara yang mudah, murah dan tepat. Semua kegiatan pada Kantor Arsip Universitas Padjadjaran tidak bisa terlepas dari sistem berbasis digital dalam memenuhi kebutuhan komunikasinya. Media digital saat ini sudah seharusnya digunakan oleh public relations pada KantorArsip Universitas Padjadjaran untuk mendukung dan membentuk digital branding. Penelitian ini bertujuan untuk mengetahui digital branding pada Kantor Arsip Universitas Padjadjaran, melalui analisis kegiatan, SDM dan penggunaan media sosial. Penelitian ini menggunakan metode kualitatif, jenis studi deskriptif dengan data kualitatif. Teknik pengumpulan data dilakukan melalui wawancara, observasi dan studi literatur. Hasil penelitian menunjukkan bahwa Kantor Arsip Universitas Padjadjaran telah melakukan digital branding untuk membangun goodwill dan juga untuk memperkuat reputasinya melalui berbagai kegiatan seperti kerjasama, webinar, sosialisasi dan pembinaan kearsipan baik untuk internal maupun eksternal. Media digital yang digunakan untuk membangun branding masih terbatas pada situs website. Media sosial seperti facebook, Instagram, tweeter, line dan lain-lain belum dimanfaatkan oleh Kantor Arsip Universitas Padjadjaran. Pengelolaan kegiatan public relations dilakukan oleh arsiparis yang belum mendapatkan Pendidikan dan pelatihan kehumasan.
\end{abstract}

Kata-kata Kunci: kantor arsip; public relations; digital branding; media sosial; reputasi

\section{Digital branding of the Archives Office of the University of Padjadjaran}

\section{to strengthen the reputation}

\begin{abstract}
The Archives Office of the University of Padjadjaran, as an institution, was formed to save essential archives related to evidence of the intellectual status and develop the potential that gives birth to innovation and other intellectual works that is proof of performance accountability and material for accountability for the achievements of the Tri Dharma of Higher Education. In the current digital era, the institution is facing a very open situation, where the public must easily access information related to static archives in an easy, cheap, and precise way. Therefore, all activities cannot be separated from a digital-based system in meeting their communication needs, especially digital media, to support and shape the digital branding of the institution. This study aims to determine digital branding at the Archives Office of the University of Padjadjaran through an analysis of activities, human resources, and social media use. This study uses a qualitative method, with data collection techniques through interviews, observations, and literature studies. The results show that the Archives Office of Padjadjaran University has carried out digital branding to build goodwill and strengthen its reputation through various activities such as cooperation, webinars, socialization, and archiving development for the internal and external public. However, digital media used is still limited to the website, while not being able to utilize social media such as Facebook, Instagram, tweeter, and line. At the same time, archivists who have not received public relations education and training carry out public relations activities.
\end{abstract}

Keywords: Archive office; public relations; digital branding; social media; reputation

Korespondensi: Wawat Setiawati, S.IP. Universitas Padjadjaran. Jalan Raya Bandung Sumedang KM 21 Jatinangor 45363.Email: wawat.setiawati@unpad.ac.id 


\section{PENDAHULUAN}

Undang-Undang No. 43 Tahun 2009 tentang Kearsipan telah mengamanatkan setiap perguruan tinggi untuk membentuk arsip perguruan tinggi yang merupakan sebuah lembaga kearsipan perguruan tinggi. Tujuan dibentuknya lembaga kearsipan perguruan tinggi adalah untuk menyelamatkan arsip penting yang berkaitan dengan bukti status intelektualitas serta mengembangkan potensi yang melahirkan inovasi dan karya-karya intelektual lainnya, yang berasal dari setiap unit kerja baik tingkat rektorat, fakultas, unit pelaksana teknis (UPT) dan lembaga-lembaga lainnya. Di samping itu lembaga kearsipan juga wajib melakukan pembinaan kearsipan.

Berdasarkan amanat yang harus dijalankan sebagaimana tercantum dalam Undang-Undang No. 43 tentang kearsipan tersebut, maka pada bulan Juli 2013 Universitas Padjadjaran mulai membentuk lembaga kearsipan perguruan tinggi, dengan nama Unit Pelaksana Teknis (UPT) dan dikukuhkan dengan Keputusan Menteri Pendidikan dan Kebudayaan No. 46 Tahun 2013 tentang Struktur Organisasi dan Tata Kerja Universitas Padjadjaran. Berbagai program kerja mulai dilaksanakan mulai dari sosialisasi, pengadaan SDM, sarana-prasarana, pendidikan dan pelatihan (Diklat) sampai pada penetapan berbagai peraturan Rektor
Universitas Padjadjaran terkait kearsipan.

UPT Kearsipan Universitas Padjadjaran dalam perkembangannya berubah status menjadi Kantor Arsip Universitas Padjadjaran, berdasarkan Peraturan Rektor Universitas Padjadjaran Nomor 1 Tahun 2020 (pasal 40) tentang Struktur Organisasi dan Tata Kerja Pengelola Universitas Padjadjaran.

Sebagai sebuah organisasi, Kantor Arsip Universitas Padjadjaran menampilkan segala aktivitasnya untuk mencapai tujuan yang telah ditetapkan melalui komunikasi organisasi, yang diarahkan ke dalam maupun ke luar organisasi atau publik sebagai sasaran tujuannya.

Pengelolaan kearsipan merupakan tanggungjawab semua pihak yang menjadi bagian dari sebuah organisasi. Kantor Arsip Universitas Padjadjaran mempunyai kewajiban untuk menyampaikan masalah kearsipan ini kepada civitas akademika, maupun stakeholder. Kenyataan dilapangan menunjukkan bahwa komunikasi mengenai kearsipan ini baru menyentuh arsiparis dan pengelola arsip/tenaga kependidikan, dan belum menyentuh semua kalangan di lingkungan Universitas Padjadjaran. Banyak kalangan yang belum mengetahui fungsi dari Kantor Arsip Universitas Padjadjaran. Hal ini mengakibatkan dukungan terhadap pengelolaan atau kegiatan kearsipan di setiap unit kerja belum optimal. Kantor Arsip Universitas Padjadjaran perlu melakukan: 1) Penyusunan 
program kerja yang jelas, sistematis, logis, terukur dan berkesinambungan; 2) Melakukan pembinaan, pengkajian dan pengembangan SDM untuk mendukung kinerja organisasi; 3) Melakukan pengelolaan arsip secara efisien dan efektif, agar fungsi layanan informasi terwujud; 4) melakukan penyelamatan informasi dan fisik arsip; 5) Melakukan pemasyarakatan kearsipan kepada publik internal maupun eksternal secara tepat sasaran, untuk mewujudkan peningkatan apresiasi; 6) Menyiapkan sistem jaringan teknologi komunikasi dan informasi; 7) Melakukan pelayanan jasa kearsipan; 8) Menyiapkan peraturan perundang-undangan dan pedoman teknis sebagai upaya percepatan pembinaan; 9) Melakukan pengawasan dan evaluasi (Galus, 2008)

Berbagai kegiatan atau program kerja yang harus dilakukan kantor arsip tersebut perlu dikomunikasikan kepada publik dengan baik melalui penggunaan media. Komunikasi yang baik sangat penting bagi efektivitas pekerjaan. Penggunaan media sebagai alat komunikasi oleh Kantor Arsip Universitas Padjadjaran, memegang peranan yang sangat penting. Komunikasi melalui media akan mendukung suasana kondusifkarena informasi berjalan lancar, sehingga akan mampu meningkatkan kinerja karyawan sekaligus sekaligus kinerja organisasi (Krismanti, 2014). Efek yang ditimbulkan dari komunikasi melalui media adalah terdapat pengertian, penerimaan, dan kerjasama serta kesamaan persepsi dalam melaksanakan manajemen kearsipan.

Di usianya yang masih muda, Kantor Arsip Universitas Padjadjaran harus terus berbenah diri dan melakukan berbagai kegiatan kearsipan dan juga kegiatan public relations agar keberadaannya dapat diketahui dan dirasakan oleh civitas akademika Universitas Padjadjaran terutama arsiparis, dan masyarakat. Berbagai kegiatan yang telah dilaksanakan tersebut perlu dipublikasikan melalui berbagai media, untuk mendukung kinerja. Media merupakan alat komunikasi, atau sarana yang disertai dengan teknologi, koran merupakan representasi dari media cetak, radio sebagai media audio, televisi sebagai media audio-visual merupakan representasi dari media elektronik, dan internet merupakan representasi dari media online (dalam jaringan) (Nasrullah, 2015).

Jalinan hubungan positif dengan publik internal maupun eksternal perlu diupayakan, dan diperlukan peran public relations dan berbagai kegiatannya untuk menginformasikan pentingnya arsip, menjelaskan berbagai program kegiatan kearsipan, menyarankan untuk melaksanakan manajemen kearsipan pada setiap unit kerja, membujuk, mengajak dan meyakinkan civitas akademika serta masyarakat akan pentingnya pengelolaan arsip. Public relations merupakan fungsi manajemen untuk 
membangun, mempertahankan hubungan baik dan kebermanfaatan antara organisasi dengan publik yang dapat mempengaruhi kesuksesan Kantor Arsip Universitas Padjadjaran.

Kemajuan teknologi, komunikasi dan informasi telah menciptakan interaksi baru, yang bisa menghubungkan diri kepada orang lain tanpa dibatasi jarak, ruang dan waktu. Internet telah memungkinkan adanya komunikasi tidak hanya antar individu namun juga antar kelompok dalam tatanan global. Dunia saat ini seolah berada dalam satu genggaman, dimana setiap orang yang berjejaring dapat saling bertukar informasi dalam berbagai format digital, dan informasi tersebut dapat diterima secara real time. Teknologi komunikasi tentunya mempunyai pengaruh secara positif apabila digunakan untuk kepentingan yang positif, dan dalam pelaksanaannya dilakukan secara terencana dan berdasarkan hasil evaluasi.

Kemajuan teknologi komunikasi dan informasi dapat membantu dan mempermudah Kantor Arsip Universitas Padjadjaran dalam mendapatkan informasi, menyampaikan informasi, dan untuk mendapatkan feedback dari publik, serta untuk mempromosikan peran dan fungsi Kantor Arsip Universitas Padjadjaran. Di era digital saat ini, internet sudah menjadi kebutuhan yang tidak bisa dinafikan bagi Kantor Arsip Universitas Padjadjaran dan merupakan tantangan bagi public relations. Public relations Kantor Arsip Universitas Padjadjaran harus dapat memanfaatkan media digital untuk dapat membangun sistem informasi dan juga komunikasi publik yang berkualitas untuk mendukung branding Kantor Arsip Universitas Padjadjaran.

Kantor Arsip Universitas Padjadjaran harus menciptakan brand, agar mendapatkan positioning di hati civitas akademika terutama para arsiparis. Kantor Arsip Universitas Padjadjaran harus membina hubungan dengan arsiparis dan juga stakeholder, agar arsiparis dan stakeholder pada akhirnya memandang brand Kantor Arsip Universitas Padjadjaran. Brand Kantor Arsip Universitas Padjadjaran akan mempunyai dampak terhadap keterikatan emosi dengan civitas akademika, sehingga pada gilirannya civitas akademika, akan secara sukarela untuk terlibat pada berbagai kegiatan yang dilaksanakan Kantor Arsip Universitas Padjadjaran.

Hasil penelitian dari Valitov menunjukkan bahwa "ekuitas brand yang tinggi akan menimbulkan loyalitas yang tinggi” (Valitov, 2014). Brand mempunyai kekuatan dan "berdampak terhadap keterikatan emosi" (Yunus, 2019). Lebih lanjut Valitov (2014) mengatakan bahwa "branding adalah ukuran tanpa syarat dan penting untuk meningkatkan kesadaran merek dan posisi" (Valitov, 2014). Brand yang kuat, dapat memberikan multiplier 
effect terhadap eksistensi kantor Arsip Universitas Padjadjaran di tingkat regional maupun nasional. Brand menjadi faktor yang penting bagi Kantor Arsip Universitas Padjadjaran.

Brand saat ini tidak hanya menjadi alat identifikasi melainkan sudah menjadi sebuah reputasi dan goodwill yang terdapat dibalik sebuah brand. reputasi dan goodwill tersebut tentunya harus dibangun dan memerlukan perjuangan.

Branding merupakan proses untuk membangun kesadaran dan memperluas loyalitas. Dimana karyawan merupakan alat terbaik untuk dapat memberikan pelayanan terbaiknya bagi pengguna. Pengguna produk layanan barang atau jasa, merasa terikat secara rasional dan emosional untuk mempergunakan jasa layanan (Yunus, 2019). Digital branding merupakan kegiatan komunikasi pemasaran yang bertujuan membagikan informasi tentang suatu nama kepada masyarakat melalui media digital seperti web dan media sosial seperti facebook, youtube, instagram dll (Yunus, 2019). Halaman situs web harus dibuat dengan menarik, dan informasinya dapat diandalkan agar dapat menarik minat pengguna. Sementara itu dalam media sosial, sangat memungkinkan untuk berbagi teks, gambar audio dan video, sehingga dapat memperkuat kegiatan komunikasi. Dimana setiap orang dapat mengekspresikan diri pada dinding pesan, ruang obrolan dan blog sehingga menciptakan rasa kebersamaan dan mendorong keterlibatan publik untuk aktif berinteraksi dan tercipta umpan balik (Yunus, 2019).

Saat ini Kantor Arsip Universitas Padjadjaran baru memperkenalkan branding melalui website, dan belum menyentuh media sosial lainnya seperti facebook, instagram, twitter dll (Trikusumawati, 2021b). Kantor Arsip Universitas Padjadjaran belum melakukan kegiatan branding secara terorganisir. Kantor Arsip Universitas Padjadjaran masih harus dikembangkan dan memerlukan perhatian yang lebih serius, baik dari sarana prasarana, sumber daya manusianya, dan sumber dananya serta pengelolaannya. Divisi public relations yang secara khusus mengelola berbagai kegiatan yang dilakukan Kantor Arsip Universitas Padjadjaran, juga untuk mengolah arsip menjadi sebuah informasi yang berkualitas perlu dibentuk.

Peran public relations pada Kantor Arsip Universitas Padjadjaran diantaranya harus dapat mendefinisikan masalah, membuat perencanaan dan bertanggung jawab terhadap pelaksanaan program komunikasi yang dilaksanakan secara penuh. Di era digital saat ini Kantor Arsip Universitas Padjadjaran dihadapkan pada situasi yang sangat terbuka, dimana akses informasi terkait arsip statis harus mudah di akses oleh 
masyarakat dengan cara yang mudah, murah dan tepat. Berdasarkan hal tersebut maka digital branding Kantor Arsip Universitas Padjadjaran perlu dilakukan.

Teknologi komunikasi dan media baru yang berkembang dengan sangat cepat telah mengubah pola komunikasi, pola pencarian informasi dan juga pola kerja. Penggunaan PC, Laptop, dan telepon seluler yang cerdas atau smartphone serta jaringan internet telah digunakan di semua instansi tidak terkecuali pada kantor Arsip Universitas Padjadjaran. Kantor Arsip Universitas Padjadjaran tentunya memerlukan sumber daya manusia yang penuh kreatifitas dan mempunyai keinginan untuk belajar dan melakukan menyesuaikan diri dengan perkembangan teknologi, komunikasi dan informasi.

Selain itu Kantor Arsip Universitas Padjadjaran juga memerlukan sumber daya public relations yang profesional yang mempunyai kemampuan untuk mengolah arsip menjadi sebuah informasi yang berkualitas, kemampuan menggunakan teknologi komunikasi dan informasi, kemampuan menulis dengan jelas, dan juga kemampuan membuat info grafik. Sumber daya public relations yang ada pada Kantor Arsip Universitas Padjadjaran saat ini dilaksanakan oleh arsiparis yang belum mendapatkan pelatihan tentang public relations. Media sosial saat ini sudah menjadi perangkat yang dapat digunakan untuk kegiatan public relations dalam konteks komunikasi eksternal pada Kantor Arsip Universitas Padjadjaran. Media Sosial dapat memfasilitasi komunikasi antar berbagai institusi dan dengan beragam tipe audiens untuk membangun pemahaman bersama (mutual understanding). Media sosial dapat menjangkau audiens dengan lebih luas dan cepat serta mudah diakses. Melalui media sosial Kantor Arsip Universitas Padjadjaran dapat melakukan digital branding, dengan mengupload semua kegiatan kearsipan yang telah dilaksanakan. Hal lain yang dapat dilakukan kantor Asip adalah dengan meng upload informasi yang sifatnya terbuka. Arsip statis yang telah diolah menjadi suatu informasi dapat segera ditayangkan. Sehingga pengguna layanan dapat mengakses berbagai informasi yang tersedia melalui media sosial.

Media yang digunakan Kantor

Arsip Universitas Padjadjaran dalam pelaksanaan kegiatan public relations untuk menginformasikan berbagai kegiatan dan menginformasikan arsip statis yang diolah menjadi informasi baru terbatas pada website Kantor Arsip Universitas Padjadjaran di situs https://kearsipan.unpad.ac.id/profil// dan juga website tingkat Universitas Padjadjaran di situs www.unpad.ac.id. Informasi yang terdapat pada Website Kantor Arsip Universitas Padjadjaran untuk menyajikan berbagai macam informasi 
yang dapat menunjang branding Kantor Arsip Universitas Padjadjaran, masih minimal dan belum ditangani oleh seorang profesional.

Berbagai kegiatan kearsipan yang juga bisa menjadi bagian dari kegiatan public relations seperti sosialisasi, pembinaan, kerjasama, seminar, workshop, pameran, dapat di publish melalui berbagai media sosial sehingga bisa menjadi salah satu upaya dalam kegiatan digital branding. Berbagai penghargaan nasional maupun internasional dari para pendidik, tenaga kependidikan dan mahasiswa, dapat di publish melalui media sosial oleh Kantor Arsip Universitas Padjadjaran karena dapat menunjang digital branding Lembaga Kearsipan Universitas Padjadjaran.

Terkelolanya digital branding dengan baik, maka Kantor Arsip Universitas Padjadjaran telah memberikan kontribusi bagi Universitas Padjadjaran untuk menuju world class university. Salah satu tolak ukur dari world class university adalah keunggulan penelitian. Tersedianya arsip-arsip penelitian yang telah dilaksanakan para pendidik di lingkungan Universitas Padjadjaran dan terpublish melalui media sosial maka ilmu pengetahuan akan semakin berkembang, dan masyarakat dapat merasakan manfaatnya. Reputasi Kantor Arsip Universitas Padjadjaran Pun semakin baik, dan "nilai psikologisnya melebihi nilai materialnya" (Sjoraida et al., 2021).
Penguatan reputasi pada Kantor Arsip Universitas Padjadjaran salah satunya dapat dilakukan melalui digital branding. Reputasi merupakanpadanan darikatareputation(Inggris) yang berarti nama baik. Secara generik reputasi berasal dari bahasa latin re artinya beruangulang, dan putare berarti menilai (Warta, 2017). Sementara itu menurut Riel reputasi artinya "menilai lagi dan lagi tentang pro serta kontra dari subjek, seseorang, sebuah organisasi atau produk dan layanan yang dihasilkannya (van Riel, 2013). Berdasarkan pengertian tersebut dapat diartikan bahwa reputasi pada kantor Arsip Universitas Padjadjaran merupakan nama baik yang didapat melalui pemrosesan informasi, diperoleh karena adanya penilaian dan kepercayaan serta pandangan umum bahwa Kantor Arsip Universitas Padjadjaran "memiliki kualitas, karakter yang kuat, dan kemampuan tertentu yang dilihat, teruji, dapat dirasakan serta diakui masyarakat atau stakeholders" (Warta, 2017). Reputasi dipengaruhi oleh 1) kinerja organisasi; 2) muncul menjadi persoalan penting karena ada organisasi lain sebagai pembanding; dan 3) reputasi bergantung pada apa yang dilakukan organisasi dan bisa berubah (Warta, 2017).

Ketiga konsep tersebut mengisyaratkan bahwa Kantor Arsip Universitas Padjadjaran harus mempunyai kinerja dan perilaku yang sangat baik sehingga civitas akademika 
terutama arsiparis harus didorong dan diberikan motivasi untuk mau melaksanakan manajemen kearsipan dan melaksanakan berbagai kegiatan public relations. Hal ini perlu dilakukan agar reputasi Kantor Arsip Universitas Padjadjaran dapat dipertahankan bahkan ditingkatkan, karena arsip perguruan tinggi lain yang ada di Indonesia, terus memacu diri untuk menunjukkan prestasinya. Kantor Arsip Universitas Padjadjaran juga harus konsisten mengkomunikasikan secara terus menerus atas capaian kinerja yang telah diperolehnya dan berbagai kegiatan public relations yang telah dilaksanakannya. Fungsi public relations pada Kantor Arsip Universitas Padjadjaran meliputi penelitian, perencanaan, pengoordinasian, administrasi, produksi, partisipasi komunitas, nasihat (Ruslan, 2014).

Penelitian ini bertujuan untuk mengembangkan digital branding pada Kantor Arsip Universitas Padjadjaran dalam upaya penguatan reputasi melalui analisis kegiatan, SDM dan media sosial. Penelitian ini penting untuk dilakukan, karena mempunyai manfaat untuk pengembangan Kantor Arsip Universitas Padjadjaran, bahkan untuk arsip perguruan tinggi lainnya. Diharapkan penelitian ini dapat memberikan masukan terkait digital branding pada Kantor Arsip Universitas Padjadjaran.

\section{METODE PENELITIAN}

Metode yang digunakan dalam penelitian Digital Branding Kantor Arsip Universitas Padjadjaran dalam Upaya penguatan Reputasi ini menggunakan Metode Kualitatif, jenis studi deskriptif dengan data kualitatif. Dimana peneliti berusaha untuk "menemukan, mengembangkan, menguji kebenaran dan mencari kembali suatu pengetahuan dengan menggunakan metode ilmiah" (Satori \& Komariah, 2012). Dalam penelitian dengan jenis studi deskriptif, peneliti mendeskripsikan fenomena dengan cara mengeksplorasi dan memberikan gambaran secara lengkap yang berkaitan dengan masalah yang diteliti.

Pengambilan data dilakukan melalui wawancara, observasi dan studi literatur. Wawancara dilakukan secara mendalam guna "mendapatkan informasi untuk kepentingan penelitian dengan cara dialog antara peneliti dan informan" (Satori \& Komariah, 2012). Wawancara yang digunakan dalam penelitian ini adalah wawancara semi struktural, dimana penulis melakukan wawancara secara fleksibel. Panduan wawancara dipadukan dengan pengembangan topik wawancara sesuai dengan kebutuhan peneliti. Adapun alasan penulis menggunakan metode wawancara kualitatif adalah penulis dapat menggali apa yang diketahui dan dialami subjek yang diteliti, serta apa yang tersembunyi di dalam diri subjek penelitian. Selain itu apa yang ditanyakan 
peneliti kepada informan, dalam hal ini informan yang mengetahui seluk beluk Kantor Arsip Universitas Padjadjaran dan berbagai kegiatannya yaitu Anita Trikusumawati yang saat ini menjabat sebagai Kepala Kantor Arsip Universitas Padjadjaran dan Kusnandar yang menjabat sebagai Kepala UPT Kantor Arsip periode 2014 s.d. 2015. Peneliti juga menggali informasi dari Wini Rahayu yang pernah mengelola website Kantor Arsip Universitas Padjadjaran. Informasi yang di gali bisa mencakup hal-hal, yang berkaitan dengan masa lampau, masa sekarang, dan juga masa yang akan datang.

Peneliti melakukan observasi terhadap berbagai kegiatan yang dilakukan Kantor Arsip Universitas Padjadjaran, yaitu kegiatan digital branding maupun kegiatan public relations lainnya dan juga kegiatan kearsipan. Observasi yang dilakukan peneliti adalah observasi partisipatif, dimana dalam melakukan pengamatan di lokasi penelitian penulis terlibat secara langsung ke lapangan untuk menggali data sesuai dengan kenyataan. "Dengan observasi partisipatif maka data yang diperoleh akan lebih lengkap, tajam dan sampai pada tingkat makna dari setiap perilaku yang nampak" (Sugiyono \& Lestari, 2021). Tujuan observasi ini untuk mendapatkan data dan informasi yang dibutuhkan untuk menjawab masalah penelitian.
Studi literatur dilakukan agar peneliti mendapatkan referensi atau sumber rujukan teoritis tentang brand, branding, digital branding dan peran humas dalam membangun digital branding pada Kantor Arsip Universitas Padjadjaran. Studi literatur juga merupakan cara pencarian dan pengolahan data berdasarkan teori yang sudah ada sebelumnya. Studi literatur dilakukan melalui berbagai sumber tertulis berupa buku dan artikel serta dokumen yang relevan dengan permasalahan yang sedang dikaji.

Pelaksanaan penelitian dilaksanakan mulai dari pra penelitian hingga pelaksanaannya. Lokasi Penelitian dilaksanakan di Kantor Arsip Universitas Padjadjaran, karena Kantor Arsip Universitas Padjadjaran dirasa perlu untuk membentuk digital branding agar keberadaannya dapat dilihat dan dirasakan oleh civitas akademika terutama arsiparis, dan stakeholder. Disamping itu Kantor Arsip Universitas Padjadjaran harus mempertahankan bahkan meningkatkan reputasi dan eksistensinya di antara Lembaga Kearsipan Perguruan Tinggi lainnya yang ada di Indonesia. Lebih jauh Kantor Arsip Universitas Padjadjaran harus mempersiapkan diri untuk melaksanakan akreditasi.

Penentukan key informan dalam penelitian ini menggunakan teknik purposive sampling, dimana peneliti memilih individu-individu 
untuk dapat diteliti, karena mereka dapat secara spesifik memberi pemahaman tentang problem riset dan fenomena dalam penelitian Digital Branding Kantor Arsip Universitas Padjadjaran dalam Upaya penguatan Reputasi. Narasumber dalam penelitian ini adalah Kepala Kantor Arsip Universitas Padjadjaran yang sedang menjabat dan yang pernah menjabat pada periode sebelumnya, yang mempunyai peran yang sangat besar dalam membangun Kantor Arsip Universitas Padjadjaran dan juga yang membuat website sebagai perintis digital branding. Informan lainnya adalah Arsiparis yang mengelola public relations Kantor Arsip Universitas Padjadjaran, atau sumber daya manusia kearsipan yang berperan sebagai public relations pada Kantor Arsip Universitas Padjadjaran.

Analisis data dilakukan "sebelum memasuki lapangan, pada saat memasuki lapangan, selama di lapangan, dan setelah selesai di lapangan" (Satori \& Komariah, 2012). Langkah-langkah analisis data dilakukan melalui: 1) pengumpulan data, dengan observasi, wawancara, dan studi dokumentasi; 2) Reduksi data, yaitu memilih dan memilah serta merangkum data-data yang penting; 3) Penyajian data, dilakukan dengan uraian singkat, grafik atau teks yang bersifat naratif; dan 4) Penarikan kesimpulan (Sugiyono \& Lestari, 2021).

\section{HASIL DAN PEMBAHASAN}

\section{Digital branding Kantor Arsip Universitas} Padjadjaran dalam upaya penguatan reputasi telah dilaksanakan melalui pelaksanaan tugas, fungsi dan kewenangannya. Kantor Arsip Universitas Padjadjaran telah melaksanakan berbagai kegiatan kearsipan mulai dari sosialisasi kearsipan, pembinaan, kerjasama, webinar hingga ke pengelolaan arsip dinamis maupun arsip statis. Berbagai kegiatan yang telah dilakukan Kantor Arsip Universitas Padjadjaran tersebut telah dimuat pada situs Universitas Padjadjaran dan juga website Kantor Arsip Universitas Padjadjaran.

Kepala Kantor Arsip Universitas Padjadjaran, mengatakan bahwa:

"Sementara ini Lembaga Kearsipan Universitas Padjadjaran masih memanfaatkan fasilitas situs website Unpad, belum merambah ke media sosial lainnya seperti facebook dan instagram, namun ada satu pemikiran akan bersamasama dengan D4 Kearsipan Digital untuk memanfaatkan channel-channel lain" (Trikusumawati, 2021b)

Beberapa kerjasama telah dilaksanakan oleh Kantor Arsip Universitas Padjadjaran, diantaranya dengan Arsip Nasional Republik Indonesia (ANRI) sebagai instansi pembina, dalam hal "Pendidikan dan pelatihan, sertifikasi dan penilaian angka kredit" (A. Trikusumawati, wawancara 9 Juni 2021). Kerjasama dengan Pemerintah Daerah Sumedang telah dilakukan 
dalam hal "Pengembangan Sumber Daya Manusia Kearsipan dan Pembinaan Tata Kelola Kearsipan di lingkungan Pemerintah Daerah Sumedang”. (A. Trikusumawati, 9 Juni 2021). Sementara itu kerjasama dengan Komisi Informasi Jawa Barat dan Harian Umum Pikiran Rakyat kerjasama dilaksanakan dalam bentuk event yaitu:

"Pelaksanaan Webinar yang sifatnya lintas jabatan lintas unit, dimana kita bisa melihat adanya satu irisan, satu sinergi. Diharapkan dari webinar ini bisa menghasilkan sesuatu yang sifatnya menjadi rekomendasi kepada para pemangku kebijakan tentang hal-hal yang sepatutnya diantisipasi oleh merekamereka yaitu terkait regulasi sampai dengan hal-hal teknis yang belum ada sampai dengan saat ini" (Trikusumawati, 2021)

Orang yang bertugas secara khusus dengan latar belakang profesi public relations pada Kantor Arsip Universitas Padjadjaran saat ini belum ada, namun ada beberapa arsiparis yang bergabung dalam pengelolaan website Kantor Arsip Universitas Padjadjaran. Para arsiparis ini memuat berita tentang kegiatan-kegiatan yang dilakukan oleh Kantor Universitas Padjadjaran ataupun tentang arsip itu sendiri.

Sementara itu dalam wawancara yang dilakukan dengan Kepala Unit Pelaksana Teknis (UPT) kearsipan periode 2014-2015 terkait kebutuhan Profesi public relations pada Kantor Arsip Universitas Padjadjaran, mengatakan bahwa:

"Di Kantor Arsip Universitas Padjadjaran yang merupakan lembaga kearsipan perguruan tinggi memungkinkan untuk adanya divisi public relations secara mandiri, yang dalam pekerjaannya memiliki kesamaan fungsi dengan public relations Universitas namun memiliki orientasi khusus yang dikaitkan dengan target Kantor Arsip Universitas Padjadjaran, dan perlu koordinasi yang jelas dengan public relations Unpad" (Kusnandar, 2021)

Salah seorang pengelola website Lembaga Kearsipan Universitas Padjadjaran, dalam kesempatan yang lain mengatakan bahwa:

"Kantor Arsip Universitas Padjadjaran memerlukan Public Relations yang profesional dan memiliki komitmen, tanggung jawab terhadap pekerjaan, berpikiran terbuka dan mau menerima pendapat rekan kerja, menjaga hubungan baik dengan rekan kerja dan mempunyai kemauan untuk mengembangkan skill "(Rahayu, 2021).

Berdasarkan uraian tersebut dapat dikatakan bahwa Kantor Arsip Universitas Padjadjaran telah melakukan kegiatan public relations dan dapat mendukung terwujudnya digital branding, hanya tentunya perlu pengembangan lebih lanjut, agar berbagai media digital dapat dimanfaatkan dengan optimal.

Kegiatan public relations yang telah dilakukan Kantor Arsip Universitas Padjadjaran ada yang sifatnya menginformasikan kepada masyarakat tentang Universitas Padjadjaran berbasis arsip, Contohnya pemberian gelar honoris causa kepada beberapa pemimpin negara oleh Universitas Padjadjaran. Kegiatan kehumasan yang sifatnya menginformasikan 


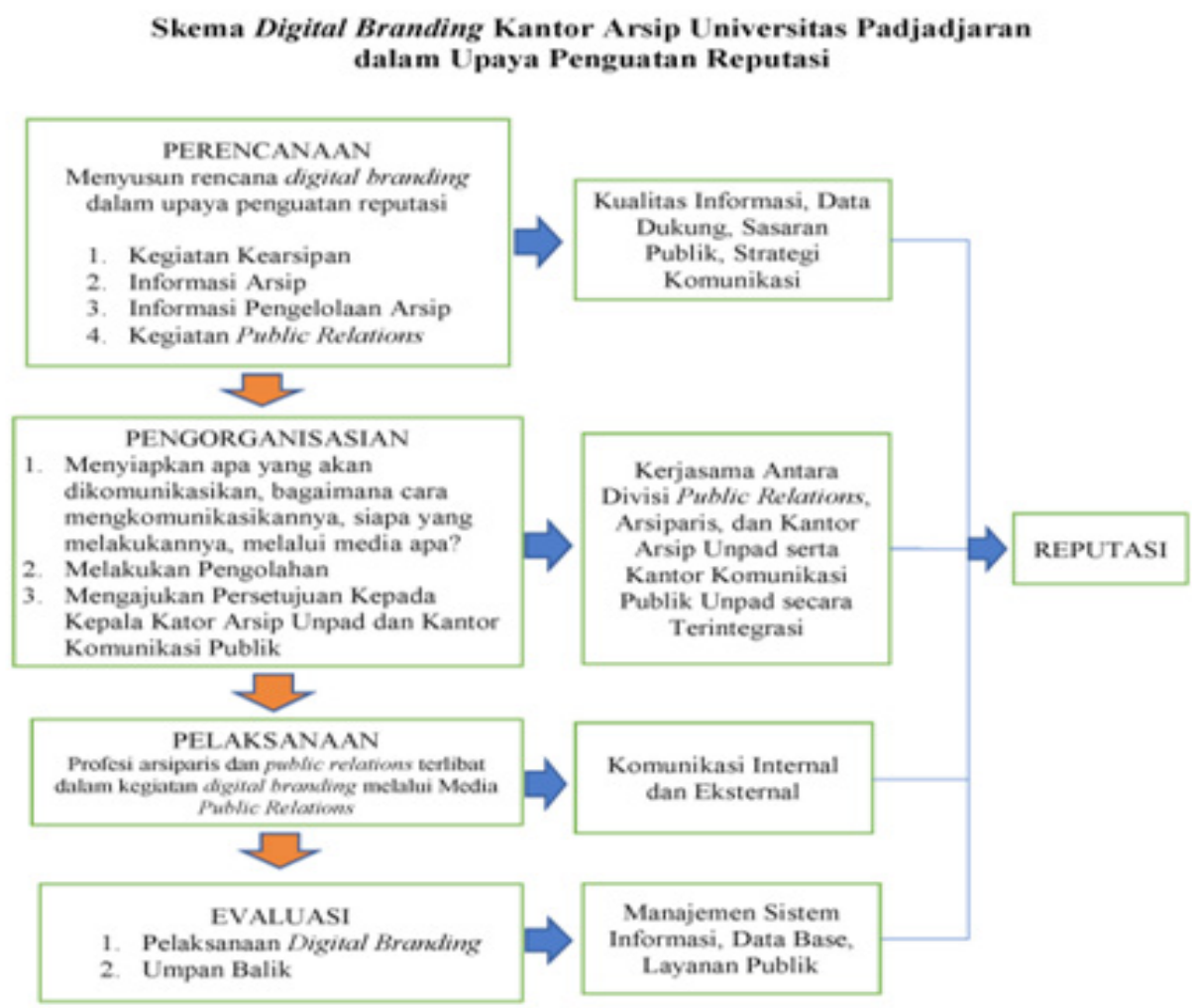

Sumber: Peneliti, 2021

Gambar 1 Skema Proses digital branding pada Kantor Arsip Universitas Padjadjaran

kepada masyarakat tentang kegiatan pembinaan kearsipan di lingkungan internal Universitas Padjadjaran. Ada juga kegiatan kehumasan yang sifatnya menginformasikan terkait kerjasama antara Kantor Arsip Universitas Padjadjaran dengan unit kerja di luar Universitas Padjadjaran dalam hal kearsipan. Juga menginformasikan kepada pihak luar khususnya kepada arsiparis terkait tugas, tanggung jawab, standar kerja arsiparis yang harus dimiliki.

Media digital saat ini sudah seharusnya digunakan oleh public relations pada Kantor Arsip Universitas Padjadjaran untuk mendukung dan membentuk digital branding.
Digital Branding merupakan kegiatan komunikasi pemasaran yang bertujuan membagikan informasi tentang suatu jenama kepada masyarakat melalui media digital (Yunus, 2019).

Proses digital branding pada Kantor Arsip Universitas Padjadjaran, penulis gambarkan pada gambar 1 .

\section{Skema digital branding Kantor Arsip} Universitas Padjadjaran dalam upaya penguatan reputasi tersebut merujuk pada fungsi dan peran manajemen dalam pencapaian tujuan organisasi yang terdiri dari 1) Perencanaan; 2) Pengorganisasian; 3) pelaksanaan; dan 4) 
Evaluasi.

Berdasarkan skema diatas dapat dijelaskan bahwa kegiatan digital branding pada kantor Arsip Universitas Padjadjaran harus dilakukan melalui perencanaan yang matang. Informasi yang dapat disajikan pada media digital dapat berupa: 1) kegiatan kearsipan; 2) Informasi Arsip; 3) Informasi Pengelolaan Arsip; dan 4) Kegiatan Public Relations. Penyajian informasi atas berbagai kegiatan tersebut tentu saja harus berkualitas, dengan disertai data dukung yang otentik dan dapat dipertanggungjawabkan. Pesan yang disampaikan terkait materi dan sasaran kegiatan tentunya memerlukan strategi komunikasi, agar tepat sasaran, dan mudah diterima yang pada akhirnya Kantor Arsip Universitas Padjadjaran mendapatkan support dari semua pihak dan reputasinya terbangun dan menjadi kuat.

Pengorganisasian terhadap kegiatan digital branding juga perlu dilakukan dengan menyiapkan bahan, kegiatan atau informasi yang akan disampaikan. Lalu tahapan berikutya adalah bagaimana cara mengkomunikasikannya, dan siapa yang diberi tanggungjawab atau diberi tugas untuk pelaksanaan kegiatan tersebut, dan media yang akan digunakannya apakah melalui website, ataukah media sosial lainnya. Pengorganisasian kegiatan digital branding tersebut perlu kerja sama antara Divisi public relations, arsiparis dan Kantor Arsip Universitas
Padjadjaran serta Kantor Komunikasi Publik secara terintegrasi. Dengan terbangunnya Kerjasama dan pengorganisasian yang baik maka dapat mendukung terbangunnya reputasi Kantor Arsip Universitas Padjadjaran.

Pelaksanaan digital branding tersebut dapat dilaksanakan oleh profesi arsiparis dan public relations. Berbagai media public relations dapat digunakan untuk pelaksanaan digital branding tersebut.

Pelaksanaan berbagai kegiatan digital branding tersebut tentu saja harus di evaluasi. Evaluasi bisa di lakukan dari umpan balik yang diberikan, dengan menggunakan manajemen sistem informasi, database dan tentu saja layanan publik

Komunikasi pemasaran yang dilakukan Kantor Arsip Universitas Padjadjaran melalui media digital mempunyai peranan yang penting agar hubungan dapat terjalin dengan kuat, sehingga ikatan emosional antara Kantor Arsip Universitas Padjadjaran, dengan civitas akademika terutama arsiparis, dan stakeholder serta masyarakat dapat tercipta. Emosional branding "mengacu pada sebuah praktik untuk membangun merek dan perusahaan melalui atau perasaan, kebutuhan, keinginan, keyakinan, dan aspirasi konsumen" (Pogorzelski, 2018).

Digital branding Kantor Arsip Universitas Padjadjaran dapat dilakukan melalui website, iklan dan video, serta media sosial. Melalui 
website pengguna dapat memilih informasi yang dibutuhkan. Website mempunyai sifat interaktif sehingga harus dibangun dengan baik agar komunikasi antara Kantor Arsip Universitas Padjadjaran dengan pengguna dapat berjalan dengan efisien dan efektif. Dalam mencari informasi tentunya pengguna akan mengunjungi Website yang dimiliki Kantor Arsip Universitas Padjadjaran. Pada website, Kantor Arsip Universitas Padjadjaran dapat menyajikan informasi terkait arsip statis yang menjadi memori institusi dan juga berbagai kegiatan kearsipan dan juga kegiatan public relations yang dilaksanakan. Pada website pengguna dapat memberikan umpan balik dan ulasan serta masukan. Website juga bisa menjadi sarana edukasi bagi arsiparis dan pengelola arsip.

Penggunaan website untuk membangun digital branding Kantor Arsip Universitas Padjadjaran memiliki beberapa keuntungan diantaranya adalah biaya yang murah, informasi dapat disampaikan secara detail, dapat menjangkau seluruh lapisan masyarakat serta tingkat penyesuaian yang tinggi untuk informasi.

Iklan dan video melalui internet dapat dirancang melalui berbagai bentuk, diantaranya melalui spanduk, teks, interaktf dll. Video terkait berbagai kegiatan, dan sejarah perjalanan lembaga serta tokoh-tokoh yang berjasa terhadap perkembangan Universitas Padjadjaran, maupun hasil karya, hasil penelitian dan prestasi dari mahasiswa, pendidik dan tenaga kependidikan dapat ditayangkan. "Iklan di internet berkembang pesat, melebihi TV” (Yunus, 2019).

Media sosial merupakan saluran atau sarana pergaulan secara online di dunia maya (Engkus et al., 2017), dan menurut (Putra, 2017) media sosial telah memasuki ranah kehidupan, mempengaruhi informal masyarakat, struktur kelembagaan, dan rutinitas professional (Putra, 2017). Media sosial saat ini berkembang begitu pesat dan dapat memperkuat komunikasi bagi Kantor Arsip Universitas Padjadjaran. Tayangan teks, gambar dan video serta audio dapat ditayangkan di media sosial dan tanpa disadari dapat mengundang publik, sehingga menjadi ajang promosi bagi karya dan inovasi mahasiswa, pendidik dan tenaga kependidikan yang dilakukan Kantor Arsip Universitas Padjadjaran. Melalui media sosial setiap orang dapat mengekspresikan dirinya melalui pesan dan ruang obrolan serta blog, sehingga rasa kebersamaan sebagai komunitas dapat tercipta, dan mereka terdorong untuk aktif berinteraksi dan bisa menjadi sarana edukasi bagi arsiparis dan pengelola arsip. Sehingga tujuan Kantor Arsip Universitas Padjadjaran dapat direalisasikan dan mendapat dukungan semua kalangan baik bagi mahasiswa, pendidik 
dan tenaga kependidikan serta masyarakat yang majemuk. Hal ini sejalan dengan pendapat Yunus Ulani yang mengatakan bahwa "Media sosial yang berbeda dapat mencapai tujuan yang berbeda (Yunus, 2019). Media merupakan sumberdaya komunikasi, yang memiliki fungsi untuk mempermudah kelancaran komunikasi, mempercepat penyampaian informasi, membantu mempercepat isi pesan yang bersifat abstrak, dan merupakan motivasi untuk melakukan komunikasi.

Praktisi public relations, dalam mengelola media sosial harus memahami dan mampu beradaptasi dengan cepat dengan perkembangan teknologi dan berbagai gadget dan aplikasinya, memahami karakter dan jumlah publik yang terlibat, ketersediaan infrastruktur yang memadai, kebijakan organisasi, dan dukungan publik praktisi public relations untuk memanfaatkan media sosial (Laksamana, 2015). Selain itu menurut Cutlip, Center dan Broom terdapat 7 aspek dalam mengelola media sosial yaitu kredibilitas, konteks, kejelasan, kontinuitas dan konsistensi, saluran dan kemampuan dari penonton (Cutlip et al., 2007). Penggunaan media sosial dapat memberikan banyak manfaat bagi organisasi dalam membangun hubungan dengan publik dan stakeholder (Kharisma \& Kurniawan, 2018). Diperlukan pendekatan strategis dalam hal tujuan, peran, tanggung jawab, kebijakan dan pedoman tentang pengelolaan media sosial antara manajemen dan praktisi public relations (Kharisma \& Kurniawan, 2018).

Brand adalah sebuah nama yang melekat pada sebuah produk barang ataupun jasa, dan mempunyai peranan yang penting bagi Kantor Arsip Universitas Padjadjaran sebagai sebuah organisasi. Pemaknaan Brand pada Kantor Arsip Universitas Padjadjaran dapat dibangun melalui program kerja, berbagai kegiatan, dan janji agar terbangun citra. Brand memiliki nilai strategis baik bagi Kantor Arsip Universitas Padjadjaran maupun bagi pengguna, untuk membedakan antara Kantor Arsip Universitas Padjadjaran yang merupakan lembaga kearsipan perguruan tinggi dengan lembaga kearsipan perguruan tinggi lainnya yang ada di Indonesia, dan juga untuk membangun citra Kantor Arsip Universitas Padjadjaran. Citra adalah "Suatu kesan yang dimiliki organisasi secara total yang berasal dari perilaku dan organisasi”" (Ardianto, 2011). Brand juga merupakan jaminan kualitas dan juga merupakan simbol harga diri.

Komunikasi melalui media sosial dapat dilakukan tanpa dibatasi jarak, batas, ruang dan waktu, serta dapat dilakukan dalam berbagai bentuk tulisan, visual maupun audio visual. Kehadiran media sosial harus dioptimalkan penggunaannya oleh Kantor Arsip Universitas Padjadjaran, karena informasi yang telah tersimpan di media sosial bisa diakses kapanpun, 
oleh siapapun dan melalui perangkat apapun.

Agar komunikasi atau penyampaian pesan yang dilakukan Kantor Arsip Universitas Padjadjaran melalui media sosial dapat berjalan dengan efektif dan efisien sesuai dengan yang diharapkan tentunya diperlukan strategi komunikasi, yang memperhitungkan faktor pendukung dan penghambat komunikasi.

Strategi komunikasi pada Kantor Arsip Universitas Padjadjaran dapat dilakukan melalui publikasi kearsipan. Menurut Hadiwardoyo (2002) publikasi kearsipan merupakan kegiatan yang mengarah pada diseminasi informasi arsip, sedangkan menurut ANRI (2008) publikasi kearsipan tidak hanya diseminasi informasi arsip tetapi juga penyampaian informasi pengelolaan arsip "how to do it" dan perkembangan khazanah $\operatorname{arsip}$ (Musliichah, 2018).

Publikasi terhadap informasi arsip tentu saja harus berdasarkan peraturan dan perundangundangan yang berlaku diantaranya UU No. 43 Tahun 2009 tentang kearsipan, Peraturan Pemerintah No. 28 Tahun 2012 tentang Petunjuk Pelaksanaan UU No. 43 Tahun 2009, UU No. 14 Tahun 2008 tentang Keterbukaan Informasi Publik, dan berbagai peraturan ANRI serta peraturan Rektor Universitas Padjadjaran.

Penyampaian pesan di media sosial, perlu penentuan khalayak yang akan menjadi sasaran komunikasi terlebih dahulu, sesuai dengan tujuan komunikasi, apakah hanya sekedar informasi atau agar komunikan melakukan tindakan tertentu. Lalu untuk mencapai sasaran komunikasi, diperlukan pemilihan media komunikasi dan media sosial yang tepat, apakah hanya akan menggunakan salah satu platform, atau menggunakan gabungan dari beberapa media tergantung pada tujuan yang hendak dicapai, pesan yang ingin disampaikan serta teknik yang akan digunakan. Teknik yang akan digunakan apakah akan menggunakan Teknik persuasi atau Teknik instruksi.

Pesan yang akan disampaikan oleh Kantor Arsip Universitas Padjadjaran harus dikaji terlebih dahulu karena pesan tersebut harus dapat dimengerti. Pesan komunikasi terdiri atas isi pesan (content of the message) dan lambang (symbol) yang akan digunakan. Peranan komunikator juga merupakan salah satu faktor penting dalam melancarkan komunikasi, dimana seorang komunikator harus mempunyai daya tarik dan kredibilitas.

Kantor Arsip Universitas Pdjadjaran merupakan sebuah organisasi nonprofit yang mempunyai fungsi dan tugas dalam penyelenggaraan kearsipan. Agar Kantor Arsip Universitas Padjadjaran dapat dibedakan dengan Lembaga Kearsipan Perguruan Tinggi lainnya yang ada di Indonesia maka perlu dibentuk Branding Kantor Arsip Universitas Padjadjaran. Branding merupakan kumpulan dari kegiatan komunikasi yang dilakukan 
Kantor Arsip Universitas Padjadjaran, untuk membangun reputasi agar semakin dikenal oleh masyarakat.

Branding sangat erat hubungannya dengan reputasi, "melakukan branding adalah memperkokoh reputasi” (Hafni \& Zaini, 2019). "Reputasi merupakan aset non fisik organisasi yang jauh lebih besar dari aset fisik" (Prayudi, 2012). Reputasi merupakan penilaian terhadap organisasi yang didalamnya melekat faktor kepercayaan dari publik (Purwindra, 2016).

Indikator pengukuran reputasi dari Fombrum dan haris disebut dengan nama The Reputation Quotient (RQ), yang terdiri dari: 1) Emotional appeal (daya tarik emosional), berkaitan dengan seberapa besar organisasi disukai/disenangi, dikagumi dan dihormati, serta dipercaya para stakeholder (feel good about, admire and respect, trust); 2) Products and services (produk dan layanan), berhubungan dengan kualitas tinggi, inovasi, nilai efisiensi, serta keandalan produk dan layanan (high quality, innovative, value for money, stands behind); 3) Financial performance (kinerja finansial), menyangkut keunggulan atas pesaing, profitabilitas, risiko minimal investasi, dan prospek yang bertumbuh (outperform its competitors, records of profitability, low risk investment, growth prospect); 4) Vision and leadership (visi dan kepemimpinan), berkenaan dengan besar tidaknya peluang pasar, kepemimpinan yang kuat dan visi ke depan yang jelas (market opportunities, excellent leadership, clear vision for the future); 5) workplace environment (lingkungan tempat kerja), dimana organisasi dikelola dengan baik dan adil dalam memberikan penghargaan kepada anggota, merupakan tempat kerja yang bagus dan melibatkan pekerja yang bagus pula (well managed/reward employees fairly, good place to work, good employees); 6) Social responsibility (tanggung jawab sosial), menyangkut sepak terjang yang banyak mendukung kegiatan masyarakat, aktif bergiat menggalang kegiatan tanggung jawab sosial, dan peduli lingkungan (good causes, social responsibility, environment responsibility) (Warta, 2017).

Membangun dan upaya mempertahankan reputasi perlu terus dilakukan oleh Kantor Arsip Universitas Padjadjaran secara konsisten, sehingga tercipta persepsi yang baik di hati civitas akademika terutama arsiparis dan juga stakeholder tentang Kantor Arsip Universitas Padjadjaran dan pada akhirnya dapat membangun awareness atas keberadaan Kantor Arsip Universitas Padjadjaran.

Membangun Branding Kantor Arsip Universitas Padjadjaran dapat dilakukan melalui media sosial terhadap produkproduk yang dihasilkan dengan kualitas yang tinggi. Public relations pada Kantor Arsip Universitas Padjadjaran harus dapat 
mengakomodir kebutuhan informasi publik dan harus membangun komunikasi dengan publik. "Eksistensi jaringan informasi yang komprehensif dan terpadu memberikan kemudahan bagi para pengguna informasi untuk mendapatkan informasi berbasis arsip yang autentik, utuh dan terpercaya" (Handayani, 2019).

Internet marketing telah menjadi faktor yang penting bagi Kantor Arsip Universitas Padjadjaran untuk membangun brand secara regional, nasional maupun internasional. Internet marketing yang tepat akan membantu Kantor Arsip Universitas Padjadjaran "membangun reputasi, memperluas jejaring, dan melakukan evaluasi kinerja" (Musty, 2012). Website kantor Arsip Universitas Padjadjaran merupakan cerminan institusi dan sumber informasi. Website yang dibangun dengan eye catching mampu meraih posisi puncak dalam pencarian melalui search engines.

Kantor Arsip Universitas Padjadjaran dalam membangun persepsi, bisa melakukan berbagai kegiatan seperti bimbingan teknis kearsipan yang dilaksanakan di desa-desa, kecamatan, sekolah dan institusi yang dilakukan oleh arsiparis yang berkompeten. Mengembangkan media digital dan media sosial seperti, twitter, website perlu dilakukan secara optimal. Kerjasama antara public relations, Arsiparis dan beberapa media perlu dilakukan.
Target Audience untuk membangun branding perlu dilakukan, untuk menentukan isi pesan dan kemasannya agar mendapat umpan balik. Umpan balik tersebut tentunya akan terjadi apabila terjadi komunikasi dua arah, dan divisi public relations aktif melakukan komunikasi melalui berbagai saluran komunikasi Hubungan baik antara Kantor Arsip Universitas Padjadjaran dengan publik perlu dijaga dengan bentuk pelayanan prima.

Brand Kantor Arsip Universitas Padjadjaran dapat diukur melalui janji Kantor Arsip Universitas Padjadjaran untuk memberikan manfaat kepada masyarakat luas, jaminan kepuasan layanan kepada pengguna, menjadi tempat belajar dan tempat mencari berbagai informasi. Brand Kantor Arsip Universitas Padjadjaran menjadi faktor terpenting dalam menunjukkan keunggulan Kantor Arsip Universitas Padjadjaran. Mengingat pentingnya brand bagi Kantor Arsip Universitas Padjadjaran, maka Kantor Arsip Universitas Padjadjaran perlu (1) menetapkan gagasan brand; (2) menentukan posisi brand yang dikaitkan dengan lembaga kearsipan perguruan tinggi lain di Indonesia; (3) melakukan analisis komparatif brand yang ada; (4) menentukan strategi brand agar memiliki daya saing yang kuat; (5) penetapan kebijakan brand.

\section{Branding Kantor Arsip Universitas} Padjadjaran dikatakan berhasil apabila mampu 
meningkatkan kualitas layanan dan khazanah arsip statisnya bertambah, pengolahan arsip statis menjadi sebuah informasi yang berkualitas dengan data dukung yang dapat dipertanggungjawabkan. Branding Kantor Arsip Universitas Padjadjaran tentunya akan terbangun apabila didukung oleh sumber daya manusia, sarana prasarana, pendanaan dan teknologi informasi dan komunikasi yang memadai.

Sumber Daya manusia (SDM) pada kantor Arsip Universitas Padjadjaran merupakan aset bagi organisasi, dan menjadi salah satu faktor yang turut menentukan keberhasilan dalam pencapaian tujuan organisasi. Tanpa sumber daya manusia yang berkualitas, tidak mungkin Kantor Arsip Universitas Padjadjaran dapat berkembang dan mencapai tujuan secara optimal. Hal ini sesuai dengan pendapat Sedarmayanti yang mengatakan bahwa "Sumber Daya manusia merupakan kemampuan potensial yang dimiliki manusia yang terdiri dari kemampuan berpikir, berkomunikasi, bertindak dan bermoral untuk melaksanakan suatu kegiatan yang bersifat teknis maupun manajerial" (Sedarmayanti, 2017).

Kemampuan potensial yang dimiliki manusia tersebut harus dikembangkan untuk menjawab tantangan di masa depan. Pengembangansumberdayamanusiamerupakan cara yang efektif untuk mengatasi ketertinggalan sumber daya manusia, keberagaman sumber daya manusia, perubahan sistem organisasi dan tata kerja. Dengan pengembangan sumber daya manusia yang baik maka Kantor Arsip Universitas Padjadjaran akan memiliki sumber daya manusia yang cakap dan terampil serta akan bekerja lebih efisien dan efektif. Kantor Arsip Universitas Padjadjaran akan mempunyai kekuatan dan mampu bersaing secara positif dalam percaturan di tingkat regional, nasional maupun internasional. Sumber daya manusia merupakan investasi yang sangat berharga, teknologi secanggih apapun tidak akan berfungsi secara maksimal apabila sumber daya manusia nya tidak kapabel, terampil, serta tidak mempunyai kreativitas. Organisasi yang berkualitas, akan selalu berupaya untuk meningkatkan pengetahuan, keterampilan dan kemampuan pegawai serta meningkatkan jenjang karier sesuai dengan kapasitas, kualitas, dan dedikasi pegawai demi kontribusi dan prestasi kerja yang prima.

Public relations pada lembaga pemerintah mempunyai dua peran yaitu sebagai manajer dan sebagai teknisi. Menurut I Gusti Ngurah Putra Public relations sebagai manajer harus mengetahui seluk beluk institusi, mempunyai kemampuan untuk melakukan penelitian, mengevaluasi program public relations, memiliki perencanaan dan kepemimpinan (Putra, 22004). Sedangkan menurut Putra 
Public relations sebagai teknisi harus mengimplementasikan program public relations yang sudah dirancang oleh manajer public relations (Komariah et al., 2016).

Public relations pada instansi pemerintah harus memberikan informasi tentang kebijakan, rencana, dan hasil kerja institusi secara teratur serta memberikan pengertian kepada publik tentang peraturan dan perundang-undangan dan segala sesuatu yang berpengaruh terhadap publik (Komariah et al., 2016). Kantor Arsip Universitas Padjadjaran membutuhkan dukungan dari civitas akademika dan masyarakat. Dalam pencapaian tujuannya diperlukan "komunikasi yang persuasif, menyenangkan dan saling menguntungkan antara organisasi dengan publiknya" (Ratnasari et al., 2018).

\section{Kantor Arsip Universitas Padjadjaran} dalam membangun reputasi, selain melakukan kegiatan digital branding, penyediaan sumber daya manusia yang kompeten dan penggunaan media sosial, komunikasi dua arah juga diperlukan agar tercipta hubungan yang baik, terbangun kepercayaan, dan menumbuhkan budaya partisipatif karyawan, sehingga kepuasan karyawan tercapai, dan pertukaran informasi antar karyawan dapat ditampung untuk pengambilan keputusan organisasi (Kriyantono, 2019). Hubungan Organisasi dengan publik akan terkelola dengan baik apabila praktisi public relations memiliki pengetahuan tentang public relations untuk melakukan analisis dalam pemecahan masalah.

\section{SIMPULAN}

Digital Branding pada Kantor Arsip Universitas Padjadjaran telah dilaksanakan dan perlu dilakukan secara terus menerus agar eksistensi dan reputasinya semakin kuat dan mendapatkan positioning di hati civitas akademika terutama arsiparis dan stakeholder. Kegiatan digital branding Kantor Arsip Universitas Padjadjaran dalam upaya penguatan reputasi merujuk pada fungsi dan peran manajemen dalam pencapaian tujuan organisasi yang terdiri dari 1) Perencanaan; 2) Pengorganisasian; 3) pelaksanaan; dan 4) Evaluasi.

Kegiatan digital branding pada kantor Arsip Universitas Padjadjaran harus dilakukan melalui perencanaan yang matang, informasi yang berkualitas, menggunakan strategi komunikasi, Pengorganisasian terhadap kegiatan digital branding dan kerja sama dengan berbagai pihak perlu dilakukan. Pelaksanaan digital branding dapat dilaksanakan oleh profesi arsiparis dan public relations, serta perlu dilakukan evaluasi. Informasi yang dapat disajikan pada media digital dapat berupa: 1) kegiatan kearsipan; 2) Informasi Arsip; 3) Informasi Pengelolaan Arsip; dan 4) Kegiatan Public Relations. 
Reputasi Kantor Arsip Universitas Padjadjaran dapat dibentuk melalui kinerja yang baik dari arsiparis, Humas Kantor Arsip Universitas Padjadjaran dan Humas yang berada di tingkat Universitas Padjadjaran, serta dukungan dari para pengambil kebijakan.

Brand KantorArsip Universitas Padjadjaran menjadi faktor terpenting dalam menunjukkan keunggulan Kantor Arsip Universitas Padjadjaran. Sinergi antara public relations pada Kantor Arsip Universitas Padjadjaran, public relations di tingkat Universitas Padjadjaran dan arsiparis perlu dilakukan dalam upaya membagun branding. Humas pada Kantor Arsip Universitas Padjadjaran mempunyai kekhasan dimana dalam membangun branding-nya harus mengedepankan kekhasan dan keunggulan dari Kantor Arsip Universitas Padjadjaran dibandingkan Lembaga Kearsipan Perguruan Tinggi lainnya yang ada di Indonesia.

Arsiparis dapat berperan sebagai public relations pada Kantor Arsip Universitas Padjadjaran dan perlu mendapatkan pelatihan dan pendidikan terkait kehumasan, mengolah arsip menjadi sebuah informasi dan juga pelatihan mengenai penggunaan berbagai media elektronik. Demikian juga dengan praktisi public relations yang ada di tingkat Universitas Padjadjaran perlu mendapatkan pendidikan dan pelatihan mengenai kearsipan agar komunikasi antara public relations di tingkat Universitas
Padjadjaran dan Kantor Arsip Universitas Padjadjaran, serta arsiparis dapat berjalan dengan efisien dan efektif, sesuai dengan tujuan yang diharapkan.

Di era teknologi komunikasi yang berkembang begitu pesat ini, media digital bisa menjadi alat bantu bagi Kantor Arsip Universitas Padjadjaran untuk memperkenalkan khazanah kearsipan, terutama berbagai karya ilmiah yang dihasilkan oleh para pendidik, mahasiswa bahkan tenaga kependidikan. Prestasi yang telah ditorehkan oleh mahasiswa, pendidik maupun tenaga kependidikan di tingkat nasional bahkan internasional, dapat diinformasikan melalui media digital. Bahkan, capaian sejarah perjalanan dan berdirinya Universitas Padjadjaran hingga tokoh-tokoh yang memimpin Universitas Padjadjaran pada periode saat ini dan sebelumnya dapat ditayangkan dan diinformasikan kepada masyarakat, sebagai memori dan jatidiri lembaga melalui media digital.

Media yang dapat digunakan untuk digital branding Kantor Arsip Universitas Padjadjaran tidak hanya sebatas pada website, namun juga dapat menggunakan media sosial lainnya seperti facebook, tweeter, whats App, Instagram, youtube dll. Komunikasi informasi yang disampaikan melalui media digital ini harus dibuat dengan sangat menarik, sehingga pengguna tertarik dan mendapatkan respon 
positif.

\section{Digital branding Kantor Arsip Universitas} Padjadjaran memerlukanperencanaan(planing), program (Programing), penggalian fakta (fact finding), pelaksanaan program (taking action), mengkomunikasikan (communicating), dan evaluasi program (evaluating program). Hal ini perlu dilakukan agar Kantor Arsip Universitas Padjadjaran mendapatkan kepercayaan, dukungan, penghargaan dan pengertian dari civitas akademika terutama arsiparis, serta dapat menjalin kerjasama dengan semua pihak yang berkepentingan.

Strategi komunikasi pada Kantor Arsip Universitas Padjadjaran akan mampu mengatasi berbagai permasalahan yang ada, sehingga Kantor Arsip Universitas Padjadjaran berhasil melestarikan berbagai dokumen dan mendapatkan kelayakan dan kualitas dalam profesionalisme, dan kompetensi sesuai dengan standar yang berlaku. Strategi komunikasi dapat menjembatani kepentingan organisasi dengan publik.

Dinamika organisasi Kantor Arsip Universitas Padjadjaran terus berkembang, tuntutan pemenuhan kebutuhan informasi semakin tinggi, teknologi komunikasi dan informasi berkembang begitu pesat, pengaruh opini, sikap, perilaku, citra dan reputasi publik semakin besar. Sehingga perlu perencanaan yang tepat dalam menentukan strategi komunikasi pada Kantor Arsip Universitas Padjadjaran.

Strategi komunikasi diharapkan dapat mempengaruhi khalayak dan mendapatkan pengertian, penerimaan, kerjasama dan memberikan informasi serta mendapatkan feedback, sehingga terdapat timbal balik yang pada akhirnya Kantor Arsip Universitas Padjadjaran dapat menunjukkan eksistensinya. Dengan demikian maka arsiparis, pendidik dan tenaga kependidikan, bahkan masyarakat akan sering mengunjungi website dan media sosial Kantor Arsip Universitas Padjadjaran, yang pada akhirnya digital branding Kantor Arsip Universitas Padjadjaran terwujud dan mendapatkan positioning. Pengguna pun dapat memberikan ulasan bahkan masukan melalui website maupun media sosial hingga digital branding Kantor Arsip Universitas Padjadjaran dapat terbangun dengan baik dan dapat menarik minat pengguna.

\section{DAFTAR PUSTAKA}

Ardianto, E. (2011). Handbook of public relations pengantar komprehensif. Bandung: Simbiosa Rekatama Media.

Cutlip, S. M., Center, A. H., \& Broom, G. M. (2007). Effective public relations (Ed. 9). Jakarta Timur: Kencana.

Engkus, E., Hikmat, H., \& Saminnurahmat, K. (2017). Perilaku narsis pada media sosial di kalangan remaja dan upaya penanggulangannya. Jurnal Penelitian 
Komunikasi, 20(2), 121-134. https://doi. org/10.20422/jpk.v20i2.220

Galus, B. S. (2008). Urgensitas dan relevansitas kearsipan bagi negara.

Hafni, N. D., \& Zaini, A. (2019). Peran public relations dalam pembentukan branding institution perguruan tinggi keagamaan islam swasta. Tadris : Jurnal Penelitian Dan Pemikiran Pendidikan Islam, 13(1), 67-77. https://doi.org/10.51675/ JT.V13I1.58

Handayani, T. (2019). Era new public service (sebuah pemikiran untuk arsip perguruan tinggi Universitas Diponegoro). 43, 28-61.

Kharisma, T., \& Kurniawan, F. (2018). Public relations in the digital era: case studi of the use of social media by government public relations in ANRI. Jurnal InterAct, Vol. 7(1), 13-20.

Komariah, K., Nugraha, A. R., \& Perbawasari, S. (2016). Persepsi aparatur pemerintah tentang kualifikasi profesi humas. Avant Garde, 4(2), 157-173. https://journal. budiluhur.ac.id/index.php/avantgarde/ article/view/604

Krismanti, S. R. (2014). Pengaruh media internal terhadap reputasi perusahaan (survey pada pelanggan bulettin Cilacap PT. Holcim Indonesia TBK. Cilacap plant). Skripsi, Fakultas Ilmu Sosial dan Humaniora Universitas Islam Negeri Sunan Kalijaga Yogyakarta.

Kriyantono, R. (2019). Public relations activities of state universities based on excellence theory. Avant Garde, 7(2), 154-170. https:// doi.org/10.36080/AG.V7I2.901

Kusnandar. (2021). Public relations pada kantor arsip Universitas Padjadjaran, 9 Februari 2021.

Laksamana, A. (2015). Profesi public relations indonesia dalam era digital. Jurnal Public
Relations Indonesia, 2(3), 6-16.

Marconi, J. (2004). Public relations: the complete guide. Belmon: Thomson Learning.

Musliichah,M.(2018). Strategic communication dalam mempertahankan eksistensi arsip UGM sebagai pilot project lembaga kearsipan perguruan tinggi di Indonesia. Diplomatika: Jurnal Kearsipan Terapan, 1(2), 93-107. https://doi.org/10.22146/ DIPLOMATIKA.35202

Musty, B. (2012). Membangun branding melalui pengembangan internet marketing dalam sektor pendidikan. Jurnal LPKIA, 1(2), 1-6.

Nasrullah, R. (2015). Media sosial: perspektif komunikasi, budaya, dan sosioteknologi. Bandung: Simbiosa Rekatama Media.

Pogorzelski, J. (2018). Emotional branding. Managing Brands in 4D, February, 59-109. https://doi.org/10.1108/978-1-78756-102120181004.

Prayudi. (2012). Public relations stratejik. In Komunikasi UPN Press (Vol. 80, Issue 20).

Purwindra, M. B. (2016). Peran humas badan pusat statistik sebagai pengelola manajemen reputasi di era keterbukaan informasi publik. Jurnal Kajian Komunikasi, 7(1), 71-82.

Putra, N. A. (2017). Literasi media sosial humas pemerintah daerah. Informasi, 47(2), 271. https://doi.org/10.21831/informasi. v47i2.17235

Putri, N. E., Hakim, N., \& Yamin, M. (2016). Ecologicall footprint and biocapacity analysis for flooding prevention in South Sumatera. Jurnal Mimbar, 32(1), 58-64.

Rahayu, W. (2021). Sumber daya public relations pada kantor arsip Universitas Padjadjaran, 12 Februari 2021.

Ratnasari, E., Rahmat, A., \& Prastowo, F. A. 
A. (2018). Peran humas perguruan tinggi negeri badan hukum dalam implementasi kebijakan keterbukaan informasi. PRofesi Humas, 3(1), 21-38. https://jurnal.unpad. ac.id/profesi-humas/article/view/14034

Ruslan, R. (2014). Manajemen public relation, media komunikasi konsepsi dan aplikasi. Jakarta: Raja Grapindo Persada.

Satori, D., \& Komariah, A. (2012). Metode penelitian kualitatif. Bandung: Alfabeta.

Sedarmayanti. (2017). Perencanaan dan pengembangan sumber daya manusia untuk meningkatkan kompetensi, kinerja, dan produktivitas kerja. Bandung: Refika Aditama.

Sjoraida, D. F., Dewi, R., Adi, A. N., \& Dipa, A. K. (2021). Penggunaan media sosial dalam membangun reputasi anggota legislatif di Jawa Barat. PRofesi Humas, 6(1), 89-110. https://doi.org/10.24198/PRH.V6I1.32112 Sugiyono, \& Lestari, P. (2021). Metode penelitian komunikasi (kuantitatif, kualitatif, dan cara mudah menulis artikel pada jurnal internasional). Bandung: Alfabeta.

Trikusumawati, A. (2021a). Pemanfaatan media sosial untuk kegiatan digital branding, 9 Juni 2021.

Trikusumawati, A. (2021b). Penggunaan media Sosial, wawancara 9 Juni.

Valitov, S. M. (2014). University brand as a modern way of winning competitive advantage. Procedia-SocialandBehavioral Sciences, 152(843), 295-299. https://doi. org/10.1016/j.sbspro.2014.09.198

van Riel, C. B. M. (2013). Corporate reputation and the discipline of public opinion. In The Handbook of Communication and Corporate Reputation (pp. 11-19). Willey. https://doi.org/10.1002/9781118335529. $\mathrm{CH} 2$

Warta, W. (2017). Manajemen reputasi. Bandung: Simbiosa Rekatama Media.

Yunus, U. (2019). Digital branding teori dan praktik. Bandung: Simbiosa Rekatama Media. 